\title{
POSSIBILITIES OF A PRACTICAL USE OF THE INDOLICATOR EXPRESS-METHOD WITH NITROBLUE TETRAZOLIUM FOR THE PURPOSE OF ESTABLISHING INTRAVITAL LESIONS AND AREAS OF ISCHEMIC CHANGES IN THE SKIN AND MUSCLES
}

\author{
A.V.Kis'
}

Abstract. This paper provides information as to the demands on the use of express methods of research and the conditions of the application of test samples with nitroblue tetrazolium in the work of a forensic- medical examiner directly at the autopsy. This enables to take into account the degree of necrotic changes in the skin and muscles, to solve the problem pertaining to the establishment of intravital damage of soft tissue injuries that occurred due to a blunt trauma or ischemia.

Key words: corpse, injury, nitroblue tetrazolium, intravitam, forensic-medical examination.

Regional Bureau of Forensic Medical Examination (Kharkiv) National Medical University (Kharkiv)

Рецензент - проф. В.Т. Бачинський

Buk. Med. Herald. - 2013. - Vol. 17, № 3 (67), part 1. - P. 72-74

Надійшла до редакції 04.06.2013 року

(C) A.B. Кicь, 2013

УДК $340.6+343$

\section{Н.М. Козань}

\section{ОСОБЛИВОСТІ ДЕРМАТОГЛІФІКИ ПАЛЬЦІВ РУК ЖІНОЧОГО НАСЕЛЕННЯ ГУЦУЛЬСЬКОЇ ЕТНІЧНОЇ ГРУПИ}

ДВНЗ «Івано-Франківський національний медичний університет»

Резюме. У статті викладено результати дослідження пальцевої дерматогліфіки рук осіб жіночої статі, які належать до гуцульської етнічної групи, що проживає на території Івано-Франківської області, та осіб жіночої статі української національності, уродженців інших регіонів України. На підставі проведеного дослідження

Вступ. Проблема ідентифікації особи на сьогоднішній день є одним 3 актуальних питань судової медицини. Більшість наукових робіт у цьому напрямку присвячена удосконаленню традиційних методів, заснованих на порівнянні об'єктів ідентифікації з матеріалом, що відображає аналогічні ознаки ототожнюваної особи [4]. Одним із таких методів $\epsilon$ дактилоскопія, яка в останні роки переживає своє відродження. Дерматогліфіка (Д) в практиці судово-медичної експертизи займає важливе значення при ідентифікації невідомої особи, в тому числі у випадках дослідження масових жертв, і для вирішення питань кровної спорідненості [2, 3]. В останні роки низка авторів виконані роботи, в яких доведено, що на формування дерматогліфічного малюнка уродженців окремого регіону впливають географічні, кліматичні та інші фактори навколишнього середовища $[1,5]$.

Відсутність даних про регіональні стандарти конституції населення гуцульської етнічної групи і можливість їх використання в судово-медичних ідентифікаційних дослідженнях зумовлюють актуальність даної роботи.

Мета дослідження. Вивчити комплекс ознак гребінцевого малюнка пальців рук осіб жіночої встановлено факторні критерії диференціації зазначених груп (частота та особливості розподілу візерунків на різних пальцях рук у однієї особи).

Ключові слова: судова медицина, дерматогліфіка, ідентифікація особи.

гуцульської етнічної групи для подальшого використання отриманих даних у практиці судовомедичної експертизи при ідентифікації невідомої особи.

Матеріал і методи. Матеріалом дослідження (отриманий шляхом одномоментного нерандомізованого дослідження) слугували дерматогліфічні параметри пальців рук осіб жіночої статі віком 19-55 років, які були розподілені на дві групи: I група в кількості 50 осіб, які належать до гуцульської етно-територіальної групи, що проживає на території Івано-Франківської області, II група в кількості 55 осіб української національності, які не належать до жодної етнічної групи, що проживає на території Івано-Франківської області. Критеріями включення до дослідження були добровільна згода досліджуваного; відсутність дерматологічної та генетичної патології, вік особи старше 18 років. Критеріями виключення 3 дослідження слугували відмова на будь-якому етапі, наявність дерматологічної та генетичної патології, вік особи молодше 18 років. Процедура дерматогліфічного обстеження відповідала вимогам Гельсінської декларації (1975р.). Відбитки гребінцевого малюнка пальців рук отримані шляхом сканування їх сканером Futronic's FS80 
USB2.0 Fingerprint Scanner з використанням програми ftrScanApiEx.exe. $з$ подальшим перенесенням даних на персональний комп'ютер. Обробка отриманих даних проводилася за стандартною методикою [6], коли в макрорежимі вивчали якісні і кількісні показники дерматогліфів пальців рук. Математична обробка даних дослідження проводилася шляхом одно- та багатомірного статистичного аналізу [4].

Результати дослідження та їх обговорення. У ході дослідження були вивчені дерматогліфічні особливості жіночого населення Івано-Франківської області. Комплекси ключових ознак дозволили сформувати дерматогліфічні конституції окремих груп: корінного гуцульського населення (I група) та українців, уродженців інших регіонів (II група). Серед якісних показників пальцевої Д важливого значення, зазвичай, надають частоті візерунків пальців рук. Встановлено, що статистично достовірно $(\mathrm{p}<0,001)$ вибірка осіб жіночої статі гуцульської етнотериторіальної групи відрізняється від осіб жіночої статі української національності за показниками сумарної частоти ульнарних петель на пальцях обох рук - відповідно $19 \%$ та $61,5 \%$, сумарної частоти радіальних петель на пальцях обох рук - 32 \% та 3,5 \%, сумарної частоти дуг на пальцях обох рук - $16 \%$ та $5,6 \%$. Частота завитків та складних візерунків серед представників обох груп приблизно однакова - відповідно $19 \%$ та 23,3 \% завиткові візерунки, $4 \%$ та 6,1 \% складні візерунки. Стосовно розподілу візерунків на різних пальцях однієї особи можна відмітити, що в жінок I групи на I пальці обох рук найчастіше (40\%) траплялися завиткові візерунки, а найрідше (10\%) - ульнарні петлі; на II пальці, відповідно, - радіальні (50 \%) та ульнарні (10 \%) петлі; на III пальці найрідше (10\%) траплялися завиткові візерунки, а інші типи - приблизно з однаковою частотою; на IV пальці - найчастіше (50 \%) траплялися завиткові візерунки і не траплялися дуги; на V пальці частота усіх візерунків була приблизно однаковою. У жінок II групи на I, II та IV пальцях обох рук найчастіше траплялися радіальні петлі (42,3\% , $38,5 \%$ та 50,0 \%) та завиткові візерунки $(38,5 \%$, $46,2 \%$ та 46,5 \%); на III та V пальцях найчастіше траплялися ульнарні петлі (84,6\%); на IV та V пальцях не виявлено дуг. В однієї особи предста- вників як I, так і II груп на пальцях обох рук виявляли, переважно, два або три типи візерунків в різноманітних комбінаціях. Дельтовий індекс у I групі становив $11,2 \pm 0,4$, у II - 12,8 $\pm 0,5$.

\section{Висновок}

Таким чином, у результаті проведеного дослідження встановлено факторні критерії дерматогліфічного статусу осіб жіночої статі гуцульської етнічної групи: висока частота радіальних петель та дуг на пальцях обох рук порівняно 3 українками, уродженцями інших регіонів, а також особливості розподілу візерунків на різних пальцях у однієї особи.

Перспективи подальших досліджень. У подальшому планується вивчення пальцевої дерматогліфіки осіб жіночої та чоловічої статі інших етнічних груп, які проживають на території Івано-Франківської області (лемків та бойків) та розробка критеріїв їх диференціації.

\section{Література}

1. Андреева А.А. Фенетическая характеристика населения Якутии (по особенностям дерматоглифических рисунков) / А.А. Андреева, Е.Г. Шадрина // Междунар. ж. эксперим. образования. - 2012. - № 4. - 77-78.

2. Божченко А.П. Судебно-медицинская оценка дерматоглифических признаков пальцев рук в идентификации личности: автореф. дис. на соиск. науч. степени докт. мед. наук: спец. 14.00.24 «Судебная медицина»/ А.П. Божченко. - СПб., 2009. - 22 с.

3. Звягин В.Н. Медико-криминалистическое исследование фрагментов тел при массовом поступлении трупов / В.Н. Звягин, О.И. Галицкая, М.А. Негашева // Суд.-мед. экспертиза. - 2012. - № 2. - С. 4-7.

4. Мишагин В.П. Особенности дерматоглифической конституции жителей Тобольского региона и их судебно-медицинское значение: автореф. дис. на соиск. уч. степени канд. мед. наук: спец. 14.03.01 «Анатомия человека», 14.03.05 «Судебная медицина»/ В.П. Мишагин. - Тюмень, 2010. - $18 \mathrm{c}$.

5. Сегеда С.П. Антропологічний склад українського народу: етногенетичний аспект: автореф. дис. на здобуття. наук. ст. докт. істор. наук: спец. 07.00.05 «Етнологія», 03.00.14 «Антропологія» / С.П. Сегеда. K., 2002. $-28 \mathrm{c}$.

6. Сергиенко Л.П. Методы спортивной генетики: дерматоглифический анализ пальцев рук человека (сообщение 1) / Л.П. Сергиенко, В.М. Лишевская // Педагогіка, психологія та медико-біологічні проблеми фізичного виховання та спорту. - 2010. - № 2. C. $148-154$.

\section{ОСОБЕННОСТИ ДЕРМАТОГЛИФИКИ ПАЛЬЦЕВ РУК ЖЕНСКОГО НАСЕЛЕНИЯ ГУЦУЛЬСКОЙ ЭТНИЧЕСКОЙ ГРУППЫ}

\section{Н.Н. Козань}

Резюме. В статье изложены результаты исследования пальцевой дерматоглифики рук лиц женского пола, принадлежащих к гуцульской этнотерриториальной группе, проживающего на территории Ивано-Франковской области, и лиц женского пола украинской национальности, уроженцев других регионов Украины. На основании проведенного исследования установлено факторные критерии дифференциации указанных групп (частота и особенности распределения узоров на разных пальцах рук у одного человека).

Ключевые слова: судебная медицина, дерматоглифика, идентификация личности. 


\title{
PECULARITIES OF THE DERMATOGLYPHICS OF THE FINGERS OF THE FEMALE POPULATION OF THE HUTSUL ETHNIC GROUP
}

\begin{abstract}
N.M. Kozan'
Abstract. The paper presents the results of studies of the finger dermatoglyphics of the hands of females, belonging to the Hutsul ethnic group, living on the territory of a Ivano-Frankivsk region, and persons of the female gender of Ukrainian nationality, natives of other regions of Ukraine. Based on the research carried out by the author factor criteria were defined, differentiating the mentioned groups (the frequency and the specific characteristics of the patterns distribution on various fingers of the hands of one person).
\end{abstract}

Key words: forensic medicine, dermatoglyphics, personal identification

SHEE «National Medical University» (Ivano-Frankivsk)

Рецензент - проф. В.Т. Бачинський

Buk. Med. Herald. - 2013. - Vol. 17, № 3 (67), part 1. - P. 74-76

Надійшла до редакції 08.05.2013 року

\section{(C) Н.М. Козань, 2013 \\ УДК 616.718-001.5-073:340.6 \\ В.Л. Колесников \\ ЭКСПЕРТИЗА ЧЕРЕПНО-МОЗГОВОЙ ТРАВМЫ НА ФОНЕ ПРЕДШЕСТВУЮЩИХ ЗАБОЛЕВАНИЙ}

Николаевское областное бюро судебно-медицинской экспертизы

\footnotetext{
Резюме. Черепно-мозговая травма у лиц, страдающих хроническими заболеваниями, имеет особенности, которые усложняют проведение экспертиз и могут повлечь ошибку в экспертной оценке.
}

Ключевые слова: экспертиза закрытой черепномозговой травмы (ЗЧМТ), хроническая патология.
Анализ случаев (17 наблюдений) закрытой черепно-мозговой травмы в виде сотрясения или контузии головного мозга легкой степени, произошедшей на фоне хронических заболеваний, показал, что они имеют общие признаки:

a) часто отсутствуют объективные данные, свидетельствующие о потере сознания при травме; б) нередко свидетельствуемые описывают обстоятельства, что говорит об отсутствии ретроградной амнезии; в) имеет место позднее обращение за медицинской помощью, при нескольких обращениях - наблюдается нарастание описываемых симптомов при каждом последующем обращении; г) в анамнезе жизни отсутствуют указания на перенесенные в прошлом черепномозговые травмы, сосудистые заболевания и т.п.; д) среди описываемых клиницистами симптомов преобладают субъективные - жалобы на слабость, головную боль, тошноту, указание на потерю сознания, объективно отмечается неточность в выполнении пальценосовой пробы, шаткость в позе Ромберга, горизонтальный нистагм, симптом Гуровича-Манна, нарушение конвергенции; е) при КТ и МРТ исследованиях вскоре после травмы наблюдаются изменения паутинных оболочек, признаки гидроцефалии, наличие мелких очагов обызвествления, явления поражения шейного отдела позвоночника; ж) преобладает вегететивная и психопатическая симптоматика в виде (с) В.Л. Колесников, 2013 ранней астенизации, ощущения тревоги, страхов, акцентирования собственного состояния, эмоциональной лабильности, чувства «жара» и т.п.; з) течение заболевания носит характер плато или симптомы нарастают, затем стабилизируются, без заметной положительной динамики на фоне проводимого лечения.

Типичный пример. Мужчина 69 лет поступил в отделение нейрохирургии через сутки после травмы с жалобами на слабость, головокружение, шум в ушах, тошноту, наличие раны в лобной области . АД 160/100 мм рт. ст. Фотореакции вялые, шаткость в позе Ромберга, неуверенная пальценосовая проба. Тремор век и пальцев рук. На ЭЭГ - косвенные признаки ликворной гипертензии и очаговых изменений. Диагноз: сотрясение головного мозга, ушибленная рана лба. Выписан на 11-ые сутки с некоторым улучшением. На следующий день поступает в отделение неврологии с жалобами на головную боль в теменно-затылочной области, чувство давления на глаза, шум в голове, плохой сон, утомляемость. Астеничен, лабилен, тревожен. Болезненность глазных яблок, слабость конвергенции. Болезненность в области затылочных точек. Симптом Кернига положителен с обеих сторон. В позе Ромберга пошатывание. Симптом ГуровичаМанна положительный. Клинический диагноз: состояние после перенесенного сотрясения голо- 